\section{Early-season Production of Grafted Seedless Cucumbers in High Tunnels}

\author{
Wenjing Guan ${ }^{1,3}$, Daniel S. Egel ${ }^{2}$, Larry D. Sutterer ${ }^{1}$, and \\ Alexander D. Plummer ${ }^{1}$
}

ADDITIONAL INDEX WORDs. Cucurbita moschata, Cucumis sativus, cold hardiness, vegetative growth, yield

Summary. Seedless cucumber (Cucumis sativus) is a popular and high-value crop found in many local food markets. Worldwide, it is the third most important high tunnel crop after tomato (Solanum lycopersicum) and pepper (Capsicum annuum). One challenge of growing seedless cucumbers in high tunnels is low soil temperatures in the early season that suppress plant growth even when air temperatures would be adequate. Grafting cucumbers to enhance crop tolerance to suboptimal temperature stresses has been widely used in Asian countries. However, little information is available in the United States about graft compatibility, cold hardiness, and seasonal extension potential of growing grafted seedless cucumbers in high tunnels. In this study, we tested the effects of grafting with two winter squash (Cucurbita moschata) rootstocks ('Titan' and 'Marvel') on vegetative growth and yield of three seedless cucumbers ('Excelsior' pickling cucumber, 'Socrates' Beit Alpha cucumber, and 'Taurus' long-type cucumber) in the spring seasons of 2016 and 2017 in high tunnels located in U.S. Department of Agriculture (USDA) hardiness zone 6 . Nongrafted plants were included as controls. All grafted plants survived the suboptimal temperature stress during transplant period, whereas $59 \%$ of nongrafted plants died in the 2016 season. Irrespective of rootstock and cucumber cultivar, vine growth rates of nongrafted cucumbers in April of both years were lower than those of the grafted crops. Cucumber cultivars Excelsior and Taurus grafted onto Marvel winter squash rootstock had higher yields in May 2016 compared with the yields of the nongrafted plants in the same month. The enhanced early-season yields of grafted plants were observed on cucumber cultivars Excelsior and Socrates in 2017 regardless of rootstocks. Grafting also increased the entire season's yields of the three cucumber cultivars in 2017, but not in 2016. More comprehensive evaluations about cold tolerances of newly released cucumber rootstocks are needed. Further studies are also warranted to improve our understanding of effects of rootstock and scion interactions on cucumber growth and yield in high tunnel production.

S eedless cucumber, also known as greenhouse cucumber, is a popular and high-value crop found in many local food markets. Like tomato, cucumber is sold for premium prices in early-season markets (Curtis et al., 2012). Seedless cucumber plants are parthenocarpic with the

This research is based upon work that is supported by the National Institute of Food and Agriculture, U.S. Department of Agriculture under award number 2017-38640-26916 through the North Central Region SARE program under project number LNC17390 .

We would like to thank American Takii for donating the rootstock seeds, and Dennis Nowaskie, Shubin Saha, Yihai Wang, and Barbara Joyner for their invaluable technical assistance with the work.

${ }^{1}$ Department of Horticulture and Landscape Architecture, Purdue University, Southwest Purdue Agricultural Center, Vincennes, IN 47591

${ }^{2}$ Department of Botany and Plant Pathology, Purdue University, Southwest Purdue Agricultural Center, Vincennes, IN 47591

${ }^{3}$ Corresponding author. E-mail: guan40@purdue. edu.

https://doi.org/10.21273/HORTTECH03910-17 capacity to set fruit without pollination. There are different types of seedless cucumbers. The cucumbers with extended length often are referred to as european, english, or japanese cucumbers. They have thin skin with longitudinal ridges. European or english cultivars often are individually wrapped to prevent quality loss (Reid, 2015). Beit Alpha cucumbers are smaller, with a range of sizes (Shaw et al., 2000). Large Beit Alpha cucumbers have similar sizes to typical slicing cucumbers.
Pickling cucumbers with the parthenocarpic character are also available in the market.

Seedless cucumbers have a climbing growth habit, which allows crop trellising to maximize the use of vertical spaces. Worldwide, seedless $\mathrm{cu}^{-}$ cumber is the third most important high tunnel crop after tomato and pepper (Lamont, 2009). However, the primary use of high tunnels has been to extend the growing season for tomato, with lesser popularity of $\mathrm{cu}^{-}$ cumber in Indiana and the other states in the midwest (Knewtson et al., 2010). One challenge limiting seedless cucumber production in high tunnels is the relatively low soil temperature in early season that suppresses plant growth even when the air temperature would be adequate for cucumber production. Soil temperature lower than $63^{\circ} \mathrm{F}$ greatly inhibits absorption of water and mineral nutrients of the crop (Welbaum, 2015). In USDA plant hardiness zone 6 , soil temperature inside high tunnels in March and April is frequently less than $63^{\circ} \mathrm{F}$, which may prevent crop establishment or delay early cucumber production. As a result, it is difficult to achieve the early-season advantages for growing cucumber in high tunnels. To overcome this obstacle, heating the soil within the high tunnels is essential for early production of seedless cucumbers in Europe (den Nijs, 1980). However, this approach requires additional energy input and is less sustainable for high tunnel farmers. Presently, most cucumbers are planted in May in unheated high tunnels or open field in Indiana, and few locally produced cucumbers are available in markets before June.

Vegetable grafting is a cultural practice used for controlling biotic and abiotic stresses. A plant with specific disease resistance or stress tolerance is used as a rootstock to be grafted with a typical cultivar (called a scion) that has desirable fruit characteristics.

\begin{tabular}{llll}
\hline $\begin{array}{l}\text { Units } \\
\text { To convert U.S. to SI, } \\
\text { multiply by }\end{array}$ & U.S. unit & SI unit & $\begin{array}{l}\text { To convert SI to U.S., } \\
\text { multiply by }\end{array}$ \\
\hline 0.3048 & $\mathrm{ft}$ & $\mathrm{m}$ & 3.2808 \\
2.54 & inch $(\mathrm{es})$ & $\mathrm{cm}$ & 0.3937 \\
0.4536 & $\mathrm{lb}$ & $\mathrm{kg}$ & 2.2046 \\
1.1209 & $\mathrm{lb} / \mathrm{acre}$ & $\mathrm{kg} \cdot \mathrm{ha}^{-1}$ & 0.8922 \\
1.6093 & mile $(\mathrm{s})$ & $\mathrm{km}$ & 0.6214 \\
33.9057 & $\mathrm{Oz} / \mathrm{yard}^{2}$ & $\mathrm{~g} \cdot \mathrm{m}^{-2}$ & 0.0295 \\
$\left({ }^{\circ} \mathrm{F}-32\right) \div 1.8$ & ${ }^{\circ} \mathrm{F}$ & ${ }^{\circ} \mathrm{C}$ & $\left({ }^{\circ} \mathrm{C} \times 1.8\right)+32$
\end{tabular}


Grafted plants combine the beneficial characteristics of both the rootstock and scion plants (Lee et al., 2010). In China, almost all the cucumbers grown in fall and winter seasons in Chinese solar greenhouses are grafted (Davis et al., 2008). The adoption rate of cucumber grafting in Japan and Korea is as high as $75 \%$ (Lee et al., 2010). The primary reason for cucumber grafting in Asia is to enhance plants' tolerance to suboptimal temperatures. In addition, grafting is known to increase cucumber yield, improve fruit quality, extend harvest period, and enhance salt tolerance (Davis et al., 2008). Squash (Cucurbita maxima, C. moschata), interspecific squash hybrid (C. maxima $\times$ C. moschata), and figleaf gourd (Cucurbita ficifola) are commonly used as rootstocks for cucumber grafting (King et al., 2010).

In addition to low-temperature tolerance, interspecific squash hybrid rootstocks are tolerant to high temperatures; thus, they are preferred rootstocks for cucumber production in the summer. Cucumbers grafted onto some genotypes of winter squash rootstock produce fruit with shiny skin. These cucumbers have distinct appearance and longer shelf life. They are well received in the Japanese market (King et al., 2010). Figleaf gourd rootstocks have superior cold tolerance, but its rapid seedling growth and lack of uniform seed germination make grafting difficult (Davis et al., 2008).

Although grafting technique has been widely used in Asian and European countries, little information is available in the United States about seasonal extension potential of growing grafted cucumbers in high tunnels. To help high tunnel growers increase profitability of growing seedless cucumbers, this study was designed to explore the potential of extending the growing of seedless cucumbers in early spring by grafting with two commercial cucumber rootstocks in high tunnels.

\section{Materials and methods}

Plant materials. Three seedless cucumbers, 'Excelsior' pickling cucumber (Johnny's Selected Seeds, Winslow, ME), 'Socrates' large Beit Alpha cucumber (Johnny's Selected Seeds), and 'Taurus' long-type cucumber (Harris Seeds, Rochester, NY), were evaluated as scions grafted onto two winter squash rootstocks,
'Titan' and 'Marvel' (American Takii, Salinas, CA). Nongrafted plants of each of the three cucumber cultivars were included as controls. Transplants were grown in a greenhouse at the Southwest Purdue Agricultural Center (SWPAC) in Vincennes, IN. Rootstock and scion seeds were planted on 7 and 11 Mar. 2016, respectively, and on 17 and 19 Feb. 2017 , respectively. Seeds were sown in 50-cell trays filled with peat-based growing mix (Sun Gro Horticulture, Agawam, MA).

Cucumber grafting. Grafting was performed on 16 Mar. 2016 and 26 Feb. 2017. Plants were grafted with the hole-insertion grafting method in 2016. Briefly, the hypocotyl of a cucumber scion was inserted into a hole made at the apical meristem tissue of a rootstock plant (Guan and Zhao, 2015). Grafted plants were healed in a healing chamber that was built on the greenhouse bench with polyvinyl chloride pipe frame and plastic film cover. During the first 3 $\mathrm{d}$, temperatures inside the chamber were $28 \pm 3{ }^{\circ} \mathrm{C}$ with relative humidity close to $100 \%$. Relative humidity was gradually reduced after day 3 to around $60 \%$ after $6 \mathrm{~d}$. Plants were grafted with the one-cotyledon method in 2017 for better control of rootstock regrowth. With the onecotyledon method, the scion plant was cut at the hypocotyl and attached to the rootstock plant that has had one of the cotyledons and the apical meristem tissue removed. Postgrafting acclimation process was similar in 2017 as in 2016. Graft survival rates in both years were greater than $90 \%$ with no graft incompatibility observed.

Planting and High tunnel MANAGEMENT. The experiments were conducted in high tunnels (Rimol Greenhouse Systems, Hooksett, NH) located at SWPAC (USDA hardiness zone 6). Different high tunnels were used in 2016 and 2017 experiments. Both tunnels were gothic-style high tunnels that were $30-\mathrm{ft}$ wide and $96-\mathrm{ft}$ long, with 6 - $\mathrm{ft}$ side walls and $15-\mathrm{ft}$ centers. Before the cucumber trials, tomato was grown in both tunnels. The high tunnels were equipped with ridge vents, which opened when temperatures reached $75{ }^{\circ} \mathrm{F}$ and closed when temperatures dropped less than $60{ }^{\circ} \mathrm{F}$. The side walls were opened when temperatures were greater than $80{ }^{\circ} \mathrm{F}$.
Grafted and nongrafted cucumber seedlings were transplanted on raised beds in high tunnels on 30 Mar. 2016 and 20 Mar. 2017. Dead plants were replaced $7 \mathrm{~d}$ after the initial transplanting date. Six beds with 4 -ft center-to-center bed spacing were made inside the high tunnels. The beds were covered with black plastic mulch with one drip tape having 8 -inch emitter spacing in the middle of each bed. The inrow plant spacing was $1 \mathrm{ft}$. Double layers of $0.5-\mathrm{oz} / \mathrm{yard}^{2}$ rowcovers (GR-RC05B; Greenhouse Megastore, Los Angeles, CA) were used for frost protection in 2016, whereas double layers of $1.5-\mathrm{oz} / \mathrm{yard}^{2}$ rowcovers (GR-RC15; Greenhouse Megastore) were used in 2017. The rowcovers were placed on wired hoops that were installed in every $5 \mathrm{ft}$. Rowcovers were applied when the lowest air temperatures outside of high tunnel were predicted to be less than $40{ }^{\circ} \mathrm{F}$.

Plants were trellised to a single leader system. Suckers as well as lower leaves of each vines were pruned every week. After pruning the lower leaves, vines were dropped to the ground. Plants were maintained around 5-ft height.

FERTILITY AND PEST MANAGEMENT. Preplant fertilizers were applied to high tunnels according to soil test results. Urea $(46 \mathrm{~N}-0 \mathrm{P}-0 \mathrm{~K})$ at $30 \mathrm{lb} /$ acre nitrogen $(\mathrm{N})$ and zinc sulfate at $2.5 \mathrm{lb} /$ acre zinc $(\mathrm{Zn})$ were preplant incorporated into soils in 2016. Diammonium phosphate $(18 \mathrm{~N}-20.1 \mathrm{P}-0 \mathrm{~K})$ at $30 \mathrm{lb} /$ acre $\mathrm{N}$, zinc sulfate at $1 \mathrm{lb} /$ acre $\mathrm{Zn}$, and $43 \mathrm{lb} /$ acre gypsum were preplant incorporated in 2017. Plants were fertigated 3 weeks after transplanting with potassium nitrate [13.7N-0P-38.5K (Krista K; Yara Intl., Oslo, Norway)] and ammonium thiosulfate $(12 \mathrm{~N}-0 \mathrm{P}-0 \mathrm{~K}, 26 \%$ $S$; Plant Food Co., Cranbury, NJ) at a rate of $1 \mathrm{lb} /$ acre $\mathrm{N}$ per day in both years until the end of the season. Fertigation was applied three times per day. Bifenazate (Acramite $50 \mathrm{WS}$; Chemtura Corp., Middlebury, CT) was used to control two-spotted spider mites (Tetranychus urticae), and imidacloprid (Admire Pro; Bayer CropScience, Research Triangle Park, NC) was applied to control cucumber beetles (Acalymma vittatum and Diabrotica undecimpunctata) in both years.

Data collection. Cucumbers were harvested three times per week 
from 4 May to 31 July 2016, and from 14 Apr. to 26 June 2017 . Cucumbers were harvested at the sizes recommended by seed companies. 'Socrates' was harvested when 7-8 inches long, 'Excelsior' was harvested when $4-5$ inches long, and 'Taurus' was harvested when 8-9 inches long. Harvest date, yield, and fruit number were recorded. Cucumbers that were misshaped and had scars were separated from marketable fruit. Vine length was measured weekly from 22 Apr. to 30 June 2016 and biweekly from 30 Apr. to 23 June 2017. Vine growth rates in April, May, and June were calculated by subtracting vine length measured at the end of each month from vine length measured at the beginning of the month.

Data loggers (Pro V2; Onset, Bourne, MA) were placed in the center of the high tunnel, which automatically recorded air and soil temperatures under the rowcovers at 30-min intervals. Air temperatures were recorded at the height of plant canopies. Soil temperatures were recorded with external sensor placed at 4 -inch depth. Purdue automated weather station was located at SWPAC that automatically recorded weather information at 30-min intervals. The weather station was located $\approx 1$ mile from the high tunnels. The weather information was automatically updated at iclimate.org.

EXPERIMENTAL DESIGN AND STATISTICAL ANALYSES. Randomized complete block designs with three replications and five plants per treatment per replication were included in both years' studies. Data from the 2016 and 2017 experiments were analyzed separately. Two-way factorial analysis of variance was performed using the PROC GLIMMIX program of SAS statistical software package (version 9.4 for Windows; SAS Institute, Cary, NC). The two factors are cucumber cultivars and grafting. Each of the factors had three levels, i.e., cultivar (Socrates, Taurus, Excelsior); grafting (nongrafted cucumber plants, cucumbers grafted onto 'Titan' winter squash rootstock, and cucumbers grafted onto 'Marvel' winter squash rootstock). Fisher's least significant difference test $(\alpha=0.05)$ was conducted for multiple comparisons of different measurements among treatments.

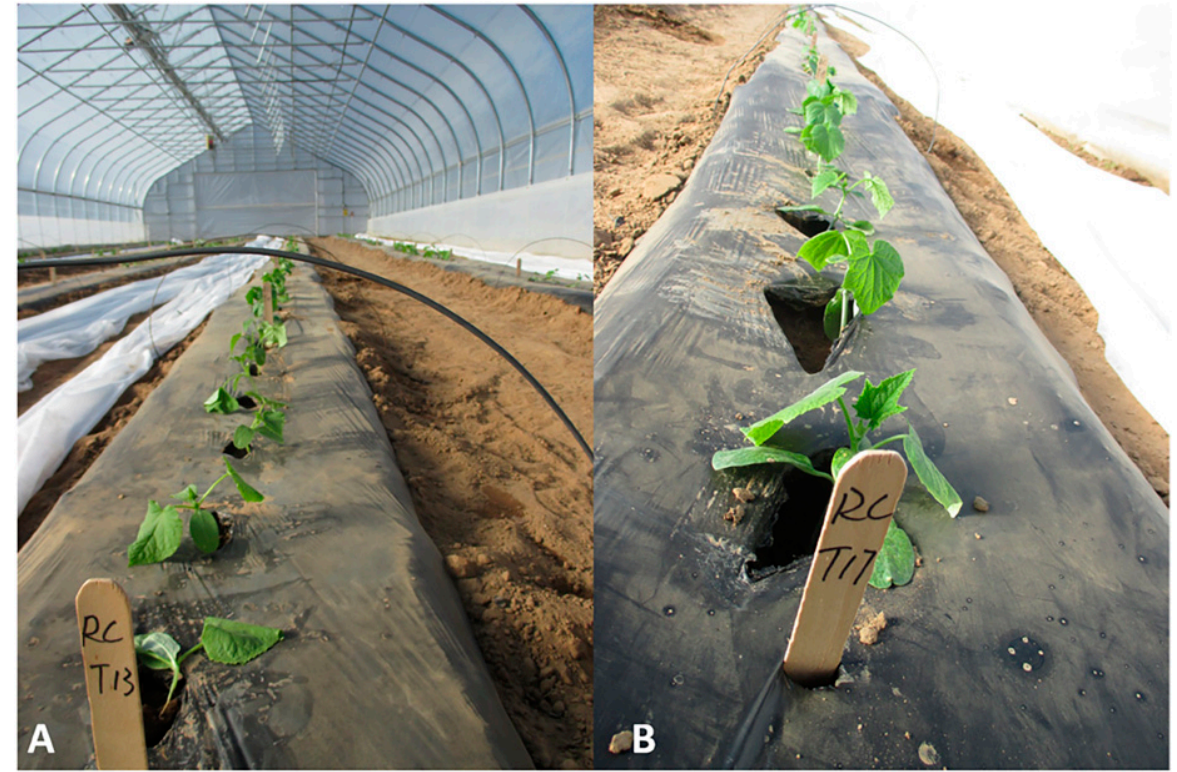

Fig. 1. Plant wilt was observed on nongrafted cucumber seedlings, but not on grafted seedlings. Photographs were taken in the morning of 2 Apr. 2016: (A) nongrafted 'Socrates' cucumber, and (B) 'Socrates' grafted onto 'Titan' winter squash rootstock.

\section{Results and discussion}

Transplant establishment. In 2016, transplant establishment failure was observed for nongrafted cucumber plants. Average among cultivars, $59 \%$ of the nongrafted cucumber plants wilted $3 \mathrm{~d}$ after transplanting, and failed to recover. No wilting symptoms were observed on grafted plants irrespective of rootstocks. All the grafted cucumbers established successfully (Fig. 1). Significant difference in transplant establishment failure was observed among grafting treatments but not among cultivars (Table 1).

The lowest air temperature outside the high tunnel after transplanting was $28^{\circ} \mathrm{F}$. Inside the high tunnel and under rowcovers, the lowest air temperature was $37^{\circ} \mathrm{F}$. Average soil temperatures outside and inside the high tunnel were 53 and $58{ }^{\circ} \mathrm{F}$, respectively (Table 2 ). Studies analyzing the effects of low temperatures on root function of young cucumber seedlings found that when soil temperatures dropped from 77 to $57^{\circ} \mathrm{F}$, positive root pressure and root hydraulic conductivity reduced by twothirds (Lee et al., 2004). The reduced root hydraulic conductance substantially inhibits plant water uptake and thus causes plant wilting (Allen and Ort, 2001). Squash rootstocks may overcome the restrictions to water
Table 1. Transplant establishment failure of cucumber plants grown in a high tunnel in 2016 at Vincennes, IN. ${ }^{2}$

\begin{tabular}{lc}
\hline Grafting effect & $\begin{array}{c}\text { Transplant } \\
\text { establishment } \\
\text { failure (\%) }\end{array}$ \\
\hline Nongrafted & $59 \mathrm{a}^{\mathrm{x}}$ \\
Titan & $0 \mathrm{~b}$ \\
Marvel & $0 \mathrm{~b}$ \\
\hline
\end{tabular}

${ }^{\mathrm{z}}$ Two-way factorial analysis of variance was performed. No cultivar by grafting interaction in transplant establishment failure was observed. Significant difference was observed among grafting effect but not cultivar effect.

${ }^{\mathrm{y}}$ Nongrafted = nongrafted 'Socrates', 'Taurus', and 'Excelsior'; Titan = 'Socrates', 'Taurus', and 'Excelsior' grafted onto 'Titan' winter squash rootstock; Marvel = 'Socrates', 'Taurus', and 'Excelsior' grafted onto 'Marvel' winter squash rootstock.

${ }^{x}$ Means within a column followed by the same letter were not significantly different by Fisher's least significant difference test $(\alpha=0.05)$.

absorption at chilling temperatures by reducing hydraulic conductance of the roots to a lesser extent (Lee et al., 2005).

Average air and soil temperatures inside high tunnel and under rowcovers were 8 and $4^{\circ} \mathrm{F}$ higher in 2017 than those in 2016 (Table 2). Less than $5 \%$ of transplant failure of nongrafted plants was observed in 2017.

Plant vine growth rate. No cultivar by grafting interactions in plant vine growth rate was observed in Apr., May, and June in 2016 and 
Table 2. Maximum ( $\max )$, minimum $(\mathrm{min})$, and average air temperatures and average soil temperature at $7 \mathrm{~d}$ after transplanting inside and outside high tunnels in 2016 and 2017 at Vincennes, IN.

\begin{tabular}{|c|c|c|c|c|c|c|c|c|}
\hline \multirow[b]{3}{*}{ Location } & \multicolumn{4}{|c|}{2016} & \multicolumn{4}{|c|}{2017} \\
\hline & $\begin{array}{l}\text { Max air } \\
\text { temp }\end{array}$ & $\underset{\text { temp }}{\text { Min air }}$ & $\begin{array}{c}\text { Avg air } \\
\text { temp }\end{array}$ & $\begin{array}{l}\text { Avg soil } \\
\text { temp }\end{array}$ & $\begin{array}{l}\text { Max air } \\
\text { temp }\end{array}$ & $\begin{array}{l}\text { Min air } \\
\text { temp }\end{array}$ & $\begin{array}{c}\text { Avg air } \\
\text { temp }\end{array}$ & $\begin{array}{l}\text { Avg soil } \\
\text { temp }\end{array}$ \\
\hline & \multicolumn{8}{|c|}{$\left({ }^{\circ} \mathbf{F}\right)^{\mathrm{z}}$} \\
\hline $\begin{array}{l}\text { Under high tunnel } \\
\text { and rowcovers }\end{array}$ & 91 & 37 & 57 & 58 & 104 & 49 & 65 & 62 \\
\hline Outside high tunnel $^{\mathrm{x}}$ & 75 & 28 & 48 & 53 & 75 & 29 & 53 & 54 \\
\hline
\end{tabular}

${ }^{\mathrm{z}}\left({ }^{\circ} \mathrm{F}-32\right) \div 1.8={ }^{\circ} \mathrm{C}$.

${ }^{y}$ Data loggers were placed in the middle of the high tunnels. It automatically recorded air and soil temperatures at 30-min intervals. Air temperatures were recorded at the height of plant canopies and the soil temperatures were recorded at 4 -inch $(10.2 \mathrm{~cm})$ depth.

${ }^{x}$ Purdue automated weather station was located at Southwest Purdue Agricultural Center (Vincennes, IN) that automatically recorded weather information at 30 -min intervals. The weather station was located $\approx 1$ mile $(1.6 \mathrm{~km})$ from the high tunnels. The temperature information was adapted from iclimate.org.

2017. However, significant differences among grafting treatments were detected in Aprils of both years. Vine growth rate of the nongrafted plants was 22.5 and $38.9 \mathrm{~cm}$ shorter than the vine growth rate of the grafted plants in Apr. 2016 and 2017, respectively (Table 3). 'Titan' and 'Marvel' winter squash rootstocks performed similarly in terms of their effects on plants' early vegetative growth in both years. Grafting did not significantly affect plant vine growth rate after April. Improved vegetative growth of grafted cucumbers under suboptimal soil temperatures was also reported when cucumbers were grafted onto figleaf gourd rootstocks (den Nijs, 1980; Zhou, et al., 2009).

The difference in growth capacities of grafted and nongrafted cucumbers at low temperatures may be attributed to different sink strengths of the roots (Schwarz et al., 2010). Roots of the grafted plants have a higher capacity to draw photosynthates from the phloem and stimulate photosynthesis rate of the scion (Amaro et al., 2014; Li et al., 2014). Coldtolerant rootstocks supply the scion with more water and nutrients under low-temperature stresses (Tachibana, 1987), which in turn stimulate photosynthesis rate and the growth of the grafted plants.

Significant differences in plant vine growth rate among cultivars were observed in both seasons. The growth rate of 'Socrates' was less than 'Taurus' in Apr. 2016, whereas the growth rate of 'Taurus' was less than 'Excesior' in May 2017 (Table 3).

Cucumber YIELD. Cucumber yields in both years were higher compared with previously reported. Yield of nongrafted 'Socrates' and 'Excelsior' was 8.5 and $6.6 \mathrm{~kg} /$ plant,

Table 3. Effect of cucumber cultivar and grafting on vine growth rate of cucumber plants grown in high tunnels in Apr. and May 2016 and 2017 at Vincennes, IN.

\begin{tabular}{|c|c|c|c|c|}
\hline \multirow[b]{3}{*}{$\underline{\text { Effect }^{\mathrm{z}}}$} & \multicolumn{2}{|c|}{2016} & \multicolumn{2}{|c|}{2017} \\
\hline & April & May & April & May \\
\hline & \multicolumn{2}{|c|}{ Vine growth rate $(\mathrm{cm})^{\mathrm{y}}$} & \multicolumn{2}{|c|}{ Vine growth rate $(\mathrm{cm})$} \\
\hline \multicolumn{5}{|l|}{ Cultivar $^{\mathrm{x}}$} \\
\hline Socrates & $46.1 \mathrm{~b}^{\mathrm{w}}$ & 124.5 & 111.9 & $141.1 \mathrm{ab}$ \\
\hline Taurus & $66.8 \mathrm{a}$ & 138.3 & 127.2 & $123.9 \mathrm{~b}$ \\
\hline Excelsior & $57.9 \mathrm{ab}$ & 136.3 & 118.6 & $148.4 \mathrm{a}$ \\
\hline Significance & ** & NS & NS & * \\
\hline \multicolumn{5}{|l|}{ Grafting $^{v}$} \\
\hline Nongrafted & $41.9 \mathrm{~b}$ & 127.1 & $93.3 \mathrm{~b}$ & 127.7 \\
\hline Titan & $68.7 \mathrm{a}$ & 142.1 & $132.4 \mathrm{a}$ & 147.1 \\
\hline Marvel & $60.0 \mathrm{a}$ & 130.0 & $131.9 \mathrm{a}$ & 138.6 \\
\hline Significance & $* * *$ & NS & $* * *$ & NS \\
\hline
\end{tabular}

${ }^{{ }^{2}}$ Two-way factorial analysis of variance was performed. No cultivar by grafting interaction in vine growth rate was observed; thus, the data were presented by cultivar and grafting effect.

${ }^{y}$ Vine growth rate was calculated by subtracting vine length measured at the end of April or May from vine length measured at the beginning of the month; $1 \mathrm{~cm}=0.3937$ inch.

'Socrates = nongrafted 'Socrates', 'Socrates' grafted onto 'Titan' winter squash rootstock, and 'Socrates' grafted onto 'Marvel' winter squash rootstock; Taurus = nongrafted 'Taurus', 'Taurus' grafted onto 'Titan' rootstock, and 'Taurus' grafted onto 'Marvel' rootstock; Excelsior = nongrafted 'Excelsior', 'Excelsior' grafted onto 'Titan' rootstock, and 'Excelsior' grafted onto 'Marvel' rootstock.

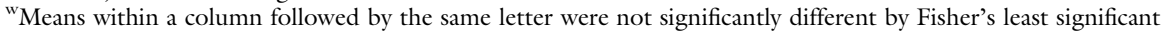
difference test $(\alpha=0.05)$.

'Nongrafted = nongrafted 'Socrates', 'Taurus', and 'Excelsior'; Titan = 'Socrates', 'Taurus', and 'Excelsior' grafted onto 'Titan' rootstock; Marvel = 'Socrates', 'Taurus', and 'Excelsior' grafted onto 'Marvel' rootstock.

Ns, ${ }^{*},{ }^{* *},{ }^{* * *}$ Nonsignificant or significant at $P \leq 0.05,0.01$, and 0.001 , respectively.

respectively, in 2016, higher than the yield of 'Socrates' ( $4.68 \mathrm{~kg} /$ plant) and 'Excelsior' (3.85 kg/plant) reported in a cucumber cultivar trial conducted in 2013 (Bogash, 2017). Yields of the nongrafted 'Taurus' were 5.5 and $5.7 \mathrm{~kg} /$ plant in 2016 and 2017 , respectively, which were higher than the yield of 'Taurus' (4.89 kg/plant) in a high tunnel cucumber trial conducted by Cornell Vegetable Program in 2012 (Reid, 2013).

Harvest started first on grafted plants on 4 May 2016. As more than $50 \%$ of nongrafted plants were replanted because of transplant failure, the harvest of the nongrafted plants was delayed for 7-10 d. By the end of May 2016, grafted 'Excelsior' onto 'Titan' rootstock had twice the yield of nongrafted 'Excelsior'. 'Taurus' grafted onto 'Marvel' rootstock also increased cucumber yield by $132 \%$ as compared with the nongrafted control (Table 4). Yields in June, July, and the entire 2016 season were similar between grafted and nongrafted plants within each cultivar, except that the number of fruit produced by 'Socrates' grafted onto 'Titan' rootstock was less than that of the nongrafted plants in July 2016.

Harvest of 'Excelsior' and 'Socrates' started on 18 Apr. 2017, and harvest of 'Taurus' started on $26 \mathrm{Apr}$. 2017. Grafting did not advance the harvest dates of any of the cultivars in 
2017. But grafted 'Socrates' and 'Excelsior' with both rootstocks had higher yields in weight in April and May compared with their nongrafted counterparts. Significant differences in yields of the entire 2017 season were detected on 'Socrates' and 'Excelsior' although total yields in fruit number were similar between grafting treatments for 'Excelsior' (Table 5). Yields were similar among grafting treatments for 'Taurus' in Apr., May, and June 2017, but 'Taurus' grafted onto 'Marvel' rootstock produced more fruit in the entire 2017 season compared with nongrafted 'Taurus' and 'Taurus' grafted onto 'Titan' rootstock. Harvest ended earlier in 2017 than in 2016 because of plant loss due to bacterial wilt (Erwinia tracheiphila). No difference in plants' susceptibility to bacterial wilt was noticed between grafted and nongrafted plants irrespective of rootstocks (data not shown).

The yield results indicated that grafting seedless cucumbers with 'Titan' and 'Marvel' rootstocks had a great potential to enhance earlyseason seedless cucumber yields. Although previous studies showed that squash rootstocks inhibited flowering of grafted cucumbers (Satoh, 1996),

Table 4. Cucumber yields per plant in May, June, and July 2016 and the entire 2016 season in a high tunnel at Vincennes, IN. ${ }^{\mathrm{z}}$

\begin{tabular}{|c|c|c|c|c|c|c|c|c|}
\hline \multirow[b]{2}{*}{ Treatment $^{\mathrm{y}}$} & \multicolumn{2}{|c|}{ May } & \multicolumn{2}{|c|}{ June } & \multicolumn{2}{|c|}{ July } & \multicolumn{2}{|c|}{ Entire 2016 season } \\
\hline & Fruit wt $(\mathrm{kg})^{\mathrm{x}}$ & Fruit (no.) & Fruit wt (kg) & Fruit (no.) & Fruit wt (kg) & Fruit (no.) & Fruit wt (kg) & $\overline{\text { Fruit (no.) }}$ \\
\hline \multicolumn{9}{|l|}{ Excelsior } \\
\hline Titan & $2.0 \mathrm{a}$ & $16.2 \mathrm{a}$ & 3.0 & 26.4 & 2.7 & 21.3 & 7.7 & 70.6 \\
\hline Marvel & $1.6 \mathrm{a}$ & $13.6 \mathrm{a}$ & 2.5 & 21.1 & 2.7 & 21.2 & 6.8 & 60.4 \\
\hline Significance & * & * & NS & NS & NS & NS & NS & NS \\
\hline Titan & 1.9 & 11.8 & 3.3 & 22.3 & 2.8 & $20.5 \mathrm{~b}$ & 8.1 & 60.4 \\
\hline Marvel & 2.1 & 12.9 & 3.5 & 23.2 & 3.0 & $21.6 \mathrm{ab}$ & 8.6 & 64.8 \\
\hline Significance & NS & NS & NS & NS & NS & * & NS & NS \\
\hline \multicolumn{9}{|l|}{ Taurus } \\
\hline Nongrafted & $0.8 \mathrm{~b}$ & $3.1 \mathrm{~b}$ & 1.9 & 8.7 & 2.8 & 19.1 & 5.5 & 35.3 \\
\hline
\end{tabular}

Table 5. Cucumber yields per plant in Apr., May, June 2017, and the entire 2017 season in a high tunnel at Vincennes, IN. ${ }^{\mathrm{z}}$

\begin{tabular}{|c|c|c|c|c|c|c|c|c|}
\hline \multirow[b]{2}{*}{ Treatment $^{\mathrm{y}}$} & \multicolumn{2}{|c|}{ April } & \multicolumn{2}{|c|}{ May } & \multicolumn{2}{|c|}{ June } & \multicolumn{2}{|c|}{ Entire 2017 season } \\
\hline & Fruit wt (kg) ${ }^{x}$ & Fruit (no.) & Fruit wt (kg) & Fruit (no.) & Fruit wt (kg) & Fruit (no.) & Fruit wt (kg) & Fruit (no.) \\
\hline \multicolumn{9}{|l|}{ Excelsior } \\
\hline Titan & $1.2 \mathrm{a}$ & $10.3 \mathrm{ab}$ & $2.3 \mathrm{a}$ & 15.2 & 2.4 & 17.4 & $5.9 \mathrm{a}$ & 43.0 \\
\hline Marvel & $1.4 \mathrm{a}$ & $12.3 \mathrm{a}$ & $2.3 \mathrm{a}$ & 16.6 & 1.7 & 16.4 & $5.3 \mathrm{a}$ & 45.3 \\
\hline Significance & * & * & * & NS & NS & NS & * & NS \\
\hline Titan & $2.7 \mathrm{a}$ & $21.3 \mathrm{a}$ & $3.4 \mathrm{a}$ & $19.8 \mathrm{a}$ & 2.7 & 16.8 & 8.9 a & $57.9 \mathrm{a}$ \\
\hline Marvel & $2.2 \mathrm{a}$ & $16.0 \mathrm{a}$ & $3.1 \mathrm{a}$ & $20.0 \mathrm{a}$ & 2.4 & 14.8 & $7.6 \mathrm{a}$ & $50.8 \mathrm{a}$ \\
\hline Significance & $\star * *$ & $* * *$ & $* * *$ & $* *$ & NS & NS & $* * *$ & $* * *$ \\
\hline \multicolumn{9}{|l|}{ Taurus } \\
\hline Nongrafted & 0.9 & 5.0 & 2.5 & 8.4 & 2.3 & 9.3 & 5.7 & $22.7 \mathrm{~b}$ \\
\hline Titan & 0.8 & 4.3 & 2.7 & 8.7 & 2.7 & 9.0 & 6.2 & $22.0 \mathrm{~b}$ \\
\hline
\end{tabular}


the inhibitory effect was not observed on the two squash rootstocks evaluated in the present study. In general, grafted cucumbers had similar yields compared with those of the nongrafted plants when environmental conditions were optimal for cucumber production in June and July. However, a negative grafting effect with the 'Titan' rootstock on fruit number of 'Socrates' was observed in July 2016. Squash interspecific hybrid rootstocks are relatively more tolerant to high temperatures (Asao et al., 1999; Davis et al., 2008). It may have a greater potential than winter squash rootstocks to extend cucumber production in later seasons.

\section{Conclusion}

This study supported previous observations that grafted cucumbers with squash rootstocks are more cold tolerant than nongrafted plants. Most of the previous studies were conducted using figleaf gourd as rootstocks. The present study showed that recent release of winter squash rootstocks are also effective in improving cucumber growth and yield under low-temperature conditions. This study indicated that cucumber grafting can be a valuable tool for high tunnel growers to extend early-season cucumber production. Without supplemental heating, grafting in conjunction high tunnel and rowcovers can extend cucumber harvest as early as in the middle of April in the USDA hardiness zone 6 , which is 1-2 months earlier than typical cucumber production in the area. More comprehensive evaluations of cold tolerance of newly released cucumber rootstocks are needed. Further studies are also warranted to improve our understanding of the effects of rootstock and scion interactions on $\mathrm{cu}^{-}$ cumber growth and yield in high tunnel production.

\section{Literature cited}

Allen, D.J. and D.R. Ort. 2001. Impacts of chilling temperatures on photosynthesis in warm-climate plants. Trends Plant Sci. 6:36-42.

Amaro, A.C.E., A.C. Macedo, A.R.P. Ramos, R. Goto, E.O. Ono, and J.D. Rodrigues. 2014. The use of grafting in improve the net photosynthesis of cucumber. Theor. Expt. Plant Physiol. 26:241-249.

Asao, T., N. Shimizu, K. Ohta, and T. Hosoki. 1999. Effect of rootstocks on the extension of harvest period of cucumber (Cucumis sativus $\mathrm{L}$.) grown in non-renewal hydroponics. J. Jpn. Soc. Hort. Sci. 68: 598-602.

Bogash, S. 2017. High tunnel trellised cucumber variety trial: 2013. 1 Jan. 2018. <https://extension.psu.edu/hightunnel-trellised-cucumber-variety-trial2013>

Curtis, K., V. Chakreeyarat, and I. Yeager. 2012. Potential pricing for locally grown produce in the extended season. Utah State Univ. Coop. Ext. Appl. Econ. 2012-2lpr. 1 Jan. 2018. <http:// citeseerx.ist.psu.edu/viewdoc/ download?doi=10.1.1.1021.2268\& rep=repl\&type=pdf .

Davis, A.R., P. Perkins-Veazie, Y. Sakata, S. López-Galarza, J.V. Maroto, S. Lee, Y. Huh, Z. Sun, A. Miguel, S.R. King, R Cohen, and J. Lee. 2008. Cucurbit grafting. Crit. Rev. Plant Sci. 27:50-74.

den Nijs, A.P.M. 1980. The effect of grafting on growth and early production of cucumbers at low temperatures. Acta Hort. 118:57-63.

Guan, W. and X. Zhao. 2015. Effects of grafting methods and root excision on growth characteristics of grafted muskmelon plants. HortTechnology 25:706713.

King, S.R., A.R. Davis, X. Zhang, and K. Crosby. 2010. Genetics, breeding and selection of rootstocks for Solanaceae and Cucurbitaceae. Scientia Hort. 127:106111.

Knewtson, S.J.B., E.E. Carey, and M.B. Kirkham. 2010. Management practices of growers using high tunnels in the central great plains of the United States. HortTechnology 20:639-645.

Lamont, W.J., Jr. 2009. Overview of the use of high tunnels worldwide. HortTechnology 19:25-29.

Lee, J.M., C. Kubota, S.J. Tsao, Z. Bie, P. Hoyos Echevarria, L. Morra, and M. Oda. 2010. Current status of vegetable grafting: Diffusion, grafting techniques, automation. Scientia Hort. 27:93-105.

Lee, S.H., S.J. Ahn, Y.J. Im, K. Cho, G.C. Chung, B.H. Cho, and O. Han. 2005.
Differential impact of low temperature on fatty acid unsaturation and lipoxygenase activity in figleaf gourd and cucumber roots. Biochem. Biophys. Res. Commun. 330:1194-1198.

Lee, S.H., A.P. Singh, G.C. Chung, S.J. Ahn, E.K. Noh, and E. Steudle. 2004. Exposure of roots of cucumber to low temperature severely reduces root pressure, hydraulic conductivity and active transport of nutrients. Physiol. Plant. 120:413-420.

Li, H., F. Wang, X.J. Chen, K. Shi, X.J. Xia, M.J. Considine, J.Q. Yu, and Y.H. Zhou. 2014. The sub/supra-optimal temperature-induced inhibition of photosynthesis and oxidative damage in cucumber leaves are alleviated by grafting onto figleaf gourd/luffa rootstocks. Physiol. Plant. 152:571-584.

Reid, J. 2013. 2012 High tunnel cucumber trial. I Jan. 2018. <https:// rvpadmin.cce.cornell.edu/uploads/doc_ 94.pdf>.

Reid, J. 2015. Best management practices in high tunnel production: Cucumbers. 1 Jan. 2018. <https://rvpadmin.cce. cornell.edu/uploads/doc_342.pdf>.

Satoh, S. 1996. Inhibition of flowering of cucumber grafted on rooted squash stock. Physiol. Plant. 97:440-444.

Schwarz, D., Y. Rouphael, G. Colla, and J.H. Venema. 2010. Grafting as a tool to improve tolerance of vegetables to abiotic stresses: Thermal stress, water stress and organic pollutants. Scientia Hort. 127:162-171.

Shaw, N.L., D.J. Cantliffe, J.C. Rodriguez, S. Taylor, and D.M. Spencer. 2000. Beit Alpha cucumber-An exciting new greenhouse crop. Proc. Florida State Hort. Soc. 113:247-253.

Tachibana, S. 1987. Effect of root temperature on the rate of water and nutrient absorption in cucumber cultivars and figleaf gourd. J. Jpn. Soc. Hort. Sci. 55:461467.

Welbaum, G.E. 2015. Vegetable production and practices. CABI, Wallingford, UK.

Zhou, Y., J. Zhou, L. Huang, X. Ding, K. Shi, and J. Yu. 2009. Grafting of Cucumis sativus onto Cucurbita ficifolia leads to improved plant growth, increased light utilization and reduced accumulation of reactive oxygen species in chilled plants. J. Plant Res. 122:529540 . 